\title{
ARTICLE \\ Analysis on the Development Path of Contemporary English Teaching in Universities and Colleges
}

\section{Shaojie $\mathbf{W u}^{*}$}

Enshi Polytechnic, Enshi, Hubei, 445000, China

\begin{tabular}{l}
\hline ARTICLE INFO \\
\hline Article history \\
Received: 25 July 2019 \\
Revised: 5 August 2019 \\
Accepted: 9 October 2019 \\
Published Online: 16 October 2019 \\
\hline
\end{tabular}

Keywords:

University and college English

English teaching

Development path

\section{Introduction}

I $\mathrm{n}$ recent years, China has made great efforts in education, and more and more foreign-funded enterprises have entered China, providing opportunities for Chinese students to find employment, therefore, more and more students are applying for English majors. In this context, it is necessary to strengthen the English teaching reform in universities and colleges, innovate teaching concepts and methods, optimize the structure of English courses, improve the evaluation mechanism of teachers, etc., improve the level of English teaching in universities and colleges, and promote the development of English teaching in universities and colleges in China.
ABSTRACT

As China's opening up to the outside world continues to increase, mastering English proficiency has become a basic requirement for Chinese citizens to move toward society and to go international. This paper focuses on the necessity of strengthening the English teaching reform in universities and colleges in China, the concept of English teaching reform and development in universities and colleges, the current problems and development path of English teaching in universities and colleges for reference.

\section{The Necessity of Strengthening the English Teaching Reform in Universities and Colleges}

Since the reform and opening up, especially since China's accession to the WTO, China's national economy has achieved rapid development. China's status and influence in the international are greatly improved. China's social development is very fast. For English teaching in universities and colleges, if we want to keep up with the pace of the times, cultivate more excellent English talents for China, and further promote China's international development, we need to strengthen the innovation of English teaching in universities and colleges. By strengthening the English teaching reform in universities and colleges, contemporary university and college students can master the language of English and apply it to the diplomatic en-

*Corresponding Author:

Shaojie Wu,

Enshi Polytechnic, No. 122 Xueyuan Road, Enshi, Hubei, 445000, China;

E-mail:978756790@qq.com. 
vironment. In addition, students will continue to contact and understand foreign cultures in the process of learning English, which will help university and college students adapt to foreign life more quickly after going abroad. In short, strengthening the English teaching reform in universities and colleges is not only the need of students' own development, but also the need to realize China's international development.

\section{The Concept of English Teaching Reform and Development in Universities and Colleges}

To carry out the English teaching reform in universities and colleges and promote the further development of English teaching in universities and colleges, we need to uphold the correct development concept. China has been offering English courses for many years, but the purpose of initially learning English is not to cultivate English talents, to promote the overall development of students, but to save the Chinese nation. Before the liberation of the Chinese nation, China experienced various wars. In the process, a group of patriotic people who studied and studied Western culture to save the motherland emerged, it can also be seen that Western culture has a great help to improve the efficiency of English learning and master English skills. Merely from a cultural point of view, economic globalization has led to two trends in the development direction of individual countries: first, the country is developing towards the overall trend of world development and pursuing synergy; second, the country continues to highlight its own characteristics and demonstrate individuality in the development process. In the past few decades, in order to obtain national liberation and enter the international market, China's development philosophy is to learn advanced science and technology from developed countries to promote the development of China's economy and gain national prosperity. In recent years, China's comprehensive national strength has been significantly enhanced, and it has a greater influence on the international stage. In the future development, we should adhere to the development concept of combining advanced technology with the highlight of the country's distinctive culture.

Therefore, English teaching in universities and colleges should promote the development of the country and improve the country's comprehensive strength as the ultimate goal of teaching, and cultivate high-quality English talents as the basic concept of teaching to promote the spread of Chinese culture, which requires that English teachers in universities and colleges should skillfully integrate Chinese culture into English teaching, so that students can better communicate the excellent culture of the Chinese nation through English and further develop cultural exchanges.

English teachers in universities and colleges need to innovate in teaching content. The teaching objectives should be toward the goal of national development, strengthen the cultivation of university and college students' oral English expression ability and writing ability, and improve students' communication ability.

\section{The Current Problems of English Teaching in Universities and Colleges}

\subsection{The Weakness of Teacher Resources}

As mentioned above, English teaching in universities and colleges is to serve China's strength and promote China's prosperity. Therefore, teachers should have a high level of professionalism and professionalism. Teachers are the disseminators of knowledge and the guides of students. In the process of English teaching, teachers must have excellent teaching ability, however, at this stage, China's English teaching in universities and colleges is still weak in terms of teacher resources, specifically including the following two points:

\subsubsection{The Quantitative Proportion of Teachers and Students in Universities and Colleges Is out of Balance}

With the increase of China's international influence and the increasing frequency of foreign cooperation and exchanges, the number of students applying for English majors has increased significantly in recent years, while the number of English teachers in universities and colleges has been limited, which makes universities and colleges have to carry out large-scale class teaching, a teacher needs to face dozens or even hundreds of students. This kind of teaching mode is not conducive to teachers to understand the learning status of students in a timely manner. Students cannot solve problems in a timely manner, and it is not conducive to teachers to manage students. This imbalance quantitative proportion of teachers and students seriously affects the quality of English teaching in universities and colleges.

\subsubsection{The Current Professional Level of English Teachers in Universities and Colleges Needs To Be Further Improved}

Because many teachers face a large number of students, the number of things to be dealt with is relatively increased, which leads to teachers having less time to study and some colleges and universities offer fewer opportuni- 
ties for learning and communication, making the professional level of teachers not effectively improved, and the teaching effect is not obvious.

\subsection{Teaching Objectives and Teaching Contents Are Confused}

Universities and colleges are the last link between schools and society. They are the last springboard for graduates to start their dreams. In addition, China's international influence is growing, and cooperation with foreign countries is gradually increasing, therefore, the objectives of English teaching in Universities and colleges should be to make students better in line with international standards, to broaden students' knowledge and improve their English ability through various effective teaching methods. However, the teaching objectives and teaching contents currently set by many universities and colleges are not clear and definite enough. Some universities and colleges set the teaching objectives to enhance the communication ability between students and foreigners, but add a lot of manpower and material resources to the teaching contents. The teaching contents are too rich and do not match the teaching objectives; in addition, the objectives set by universities and colleges are too long-term, but the contents of teaching are very simple. It is difficult to stimulate students' interest in learning and improve the efficiency of students' learning.

\subsection{The Cohesion of Each Studying Phase Is Dis- jointed, the Evaluation Is Single, and the Study- ing \& Application Are Separated}

The development of the economy and the continuous deepening of international exchanges have promoted the English studying in China to a certain extent, but students of different semester have different understanding and acceptance of English, therefore, the teaching objectives and content should be combined with the characteristics of students in different sections, but the China's current English teaching in universities and colleges still has the phenomenon of disjointed teaching between studying phases.

The English teaching plan in universities and colleges emphasizes the ability to develop students' listening, speaking, reading, and writing skills. However, in the context of exam-oriented education, this educational concept is difficult to implement ${ }^{[1]}$. Regardless of the students in every studying phase, the teaching is aimed at improving the students' academic performance. In the daily teaching, the assessment of the students is only a small class test, and the test pays more attention to the students' writing ability, which ignores the cultivation of students' ability to listen and speak. It is not difficult to see from the evaluation mechanism that whether it is primary school or university, the main purpose of learning English is to achieve good results in the exam. In order to go to key universities, postgraduate studies, or go abroad to learn English, once the purpose of learning is not linked to interests, English is left behind. Many universities and colleges only offer English courses in the first two years, and the first year of English courses is basically the study of basic words and grammar. The second year of the English course is to properly expand cultural knowledge, but the purpose of expanding cultural knowledge is also to respond to the college students' exams for the fourth and sixth grades (CET-4, CET-6). The Teaching objective is single and lacking in advancement, which makes students lack the ability to apply English. After leaving the textbook and the exam, they don't know how to use English.

\section{The Development Path of English Teaching in Universities and Colleges}

\subsection{Strengthen the Innovation of Teaching Ideas and Optimize the Curriculum Structure}

"The National Medium- and Long-Term Education Reform and Development Program (2010-2020)" clearly states that The long-term development of education needs to 'promote students' all-round development, focus on improving students' ability to serve the country, serve the people's sense of social responsibility, the innovative spirit of courage to explore and the practical ability to solve problems" ${ }^{\text {[2] }}$.

As a language subject, English major has a strong humanity, which requires English teachers in universities and colleges not only to pay attention to the cultivation of language ability in the teaching process, but also to let students understand Western culture and learn humanities knowledge, so as to enhance students' humanistic qualities and improve students' thinking logic ability. After students have the ability to think, they can better deal with the various problems encountered in life and help to promote the long-term development of students. In addition, improving students' humanistic qualities is also conducive to promoting the building of a harmonious and civilized society in China. If the formulation of English education policy is the outline, the setting of English educational institutions, the structure of English courses and the teaching methods are the details. When the outline is laid out, the details are easy to arrange, the optimization of teaching materials and teaching content has become the breakthrough of this reform ${ }^{[3]}$. 
In the process of English teaching reform and innovation in universities and colleges, strengthening the curriculum structure and optimization of teaching materials is an important content, because teaching materials and courses are the basic materials for teaching. The learning effect and development direction of students are determined by teaching materials and courses. Universities and colleges should integrate humanities education into textbooks. For example, Harvard University has launched a liberal arts education course to improve students' humanistic qualities. Therefore, for China's English teaching in universities and colleges, it is appropriate to integrate Chinese teaching and spread Chinese culture to students. At this stage, the selected textbooks must emphasize the normative nature of the language and the elegance of the content (or "humanity"), which consists of classroom textbooks and extra-curricular extended reading materials. It focuses on broadening the cultural vision, learning logical thinking, and cultivating speculative ability. For the firstyear university and college students, you can set up a language-based course. First, students should improve their language norms by touching humanities knowledge, so that students can develop good language habits and build basic humanistic ideas; for the second year of university and college students, a writing course can be established to further enhance the students' humanistic qualities by training students' thinking; for the third year of university and college students, elective courses (required or optional) can be offered to offer modern grammar, English history, translation applications, literary classics, world civilization, academic writing (understand the main academic writing standards such as MLA, APA, Chicago, etc. ${ }^{[4]}$, which allows them to learn to use the network, the library to find academic resources), linguistics (including English and Chinese, through the comparative study to find the commonalities and differences of language) and other courses, while strengthening the humanities literacy while further developing language skills.

\subsection{Update Teaching Equipment and Improve Teaching Methods}

The traditional English teaching mode is that the teacher, as the protagonist of the class, conducts "cramming teaching". The teaching equipment used is multimedia, and only uses multimedia to display the words and paragraphs of the English to the students, and to play the audio dialogues in the textbooks to the students. This kind of teaching method is very boring, which is difficult to stimulate students' interest in learning. In addition, the large number of students has increased the difficulty of popularizing teaching equipment. Therefore, schools should add teach- ing equipment, component voice classrooms, and expand the use of advanced equipment teaching equipment.

Although the teaching textbooks of the same school are the same, the teaching methods are not single. Different teachers can adopt different teaching methods according to the actual characteristics of students to meet the learning needs of students and improve the enthusiasm of students. In English education of universities and colleges, the vocabulary mastered by students is basically around 4,000 , which can meet the needs of communication, and it takes more effort in grammar learning and culture and art. Teachers can encourage students to watch more European and American film and television dramas under the class, or organize students to conduct situational exercises in the classroom, so that students can master English knowledge and ability in the process of participation.

\subsection{Improve the Teacher Evaluation Mechanism}

In the university and college English education classroom, the number of students is large, and teachers cannot take care of the performance of each student. Therefore, the most direct and effective evaluation mechanism is assessment. The traditional assessment method is mainly to assess the excellence of students through examinations. The higher the test papers, the better the students are. The evaluation mechanism is very lacking. In today's educational environment, English teachers In universities and colleges should innovate evaluation methods, taking into account the students' classroom performance, the completion of homework, and the extent of progress in the learning process. In addition, we must pay attention to students' understanding of English phonetic symbols and grammar while paying attention to students' emotional attitudes in English culture.

\subsection{Strengthen the Training of Teachers and In- troduce Excellent English Talents}

Teachers are the core of education reform, and the status of teachers cannot be ignored. From the perspective of teachers themselves, they should further enhance their sense of crisis, and continue to actively learn professional knowledge and improve their professional level and teaching level. At the same time, teachers need to constantly reflect on the teaching process and teaching results, timely discover their own shortcomings and make corrections. In addition, teachers need to strengthen exchanges, learn from each other and make progress together; from the perspective of the school, schools should provide teachers with training opportunities, encourage teachers to learn from other institutions, and enhance their professional 
ability and comprehensive quality.

In the face of the shortage of teachers' resources, only by increasing the number of teachers can we better solve the problem of the disproportionate ratio of teachers and students, which requires the school to actively introduce excellent English talents. In the selection of teachers, it is necessary not only to examine the English level of teachers, but also to examine the professional qualities and humanistic qualities of teachers, and to conduct double selection from the perspective of knowledge and morality. Great learning makes a teacher; moral integrity makes a model, this is the character of the English teachers in universities and colleges.

\subsection{English Teachers Should Enhance Their Sense of Time Management}

The teacher's management of teaching time is first of all the teacher's understanding of time management ${ }^{[5]}$. In fact, each teacher manages time to varying degrees and forms his own time management tendency. However, in real life, many teachers do not have scientific and reasonable management of their teaching time, and they are more spontaneous and scattered in the application of time, resulting in a lot of time being wasted. Teachers' awareness of management is to require scientific planning of the use of time, and to achieve time-sharing with purpose and method to improve work efficiency. English teachers in universities and colleges should clearly recognize that effective time management is a basic quality that a successful teacher should have. Learning time management and using time effectively can effectively improve the efficiency of teachers' teaching and work and enhance their professional confidence. In addition, the reasonable management time of teachers can also improve the learning efficiency of students to a certain extent, and have a corresponding impact on students, so that students can develop good ability and habits of distribution and use of time.

\section{Conclusion}

In summary, today's college English teaching needs to be further developed to train more and better talents for Chinese society. It is necessary to reform and innovate the current teaching mode, teaching system, teaching methods, etc., so as to improve teaching efficiency, promote the development of Chinese college English teaching, and promote the progress of China's educational undertakings.

\section{References}

[1] Yan Wang, Hongwei Ding. Research on College English Teaching Reform and Teacher Development Path_Comment on "College English Teaching Reform and Teacher Development Research and Exploration"'J]. Contemporary Educational Science, 2016(16):2. (in Chinese)

[2] Meirui Shi. Research on the Reform and Implementation of College English Teaching in the New Situation[J]. Journal of Jilin Teachers Institute of Engineering and Technology, 2018, 34(01):53-55. (in Chinese)

[3] Yan Zhang. Exploration and Innovation of College English Teaching Reform in the Age of "Internet +"_- Taking English Reading and Writing Teaching as an Example[J]. English Square, 2018(07):8990. (in Chinese)

[4] Pengjie Zhao. Analysis on the Development Path of English Teachers' Teaching Ability in Applied Undergraduate University-Taking Guilin Tourism College as an Example[J]. Data of Culture and Education, 2017(20):214-215+220. (in Chinese)

[5] Yinghao Jin. Research on College English Classroom Teaching under the Dynamic System Theory Framework[D].Northeast Petroleum University,2016. (in Chinese) 